\title{
Legal Analysis of Obstacles in Applicating the Extradition by Law Enforcers in Extraditing Perpetrator of Corruption Criminal Crime
}

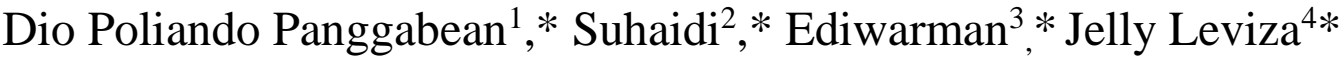

\author{
${ }^{1}$ Legal Studies Program, University of Sumatera Utara \\ ${ }^{2}$ Legal Studies Program, University of Sumatera Utara \\ ${ }^{3}$ Legal Studies Program, University of Sumatera Utara \\ ${ }^{4}$ Legal Studies Program, University of Sumatera Utara \\ Email: dio.panggabean35@gmail.com ${ }^{1}$,suhaidi@usu.ac.id ${ }^{2}$, profediwarman25@yahoo.com ${ }^{3}$,jelly@usu.ac.id je $^{4}$
}

\begin{abstract}
Indonesia has explored extradition agreements with various countries around the world, such as Malaysia, Singapore, the Philippines, Thailand, Australia, Hong Kong, Korea, China, India. Even though Indonesia has had extradition treaties with various countries, if the agreement is not ratified into the provisions of laws and regulations, the provisions cannot be applied. Extradition treaties that are not ratified are an obstacle for law enforcers in extradating perpetrators of criminal acts of corruption in other countries. The research method used in this paper is a normative legal research method. There are several factors that become obstacles in implementing extradition in which countries adhere to the Anglo-American legal system or known as the Common Law System. In this system the Indonesian government's request for extradition is entirely dependent on the decision of the court of the country concerned. In this context, the extradition treaty can actually be implemented without ratification, however, the governments of other countries may set aside the principle of reciprocity because it is greatly influenced by the policies of each requested country. For law enforcers, the ratification of the extradition treaty is one solution to extradite criminals. Some of the perpetrators of criminal acts are allegedly deliberately fleeing to countries that do not have an extradition treaty to avoid legal entanglement. Nevertheless, Indonesia seeks to extradite criminals to account for their actions.
\end{abstract}

Keywords: Analysis, Obstacles, Extradition, Law Enforcement

\section{INTRODUCTION}

Indonesia is a unitary state in the form of a republic consisting of several areas bordering other countries. Indonesia is a country that complies with and applies the provisions of international criminal law and international civil law. This is done by fostering good relations with countries and expanding relations between countries in order to realize the ideals of the nation according to the fourth paragraph of the Preamble to the 1945 Constitution of the Republic of Indonesia. The massive development of technology in the era of disruption has triggered many crimes in the world, these crimes are not only territorial but cross the territorial boundaries of a country. These crimes can only be overcome by the rule of law based on agreements and reciprocal relations between countries. [1]
In law enforcement, cooperation between countries is very important if a crime is committed across national borders. Law enforcement is carried out by entering into bilateral or multilateral agreements. Bilateral agreements can be made in the form of an extradition treaty, mutual legal assistance [2]

The implementation of extradition faces many obstacles for the law enforcers. There's a case that recently happened is quite viral and has attracted international attention. Djoko Tjandra, a fugitive for 11 years, was finally arrested because he wanted to file a judicial review regarding the legal problems he was facing. Djoko Tjandra was arrested in Malaysia by the Criminal Investigation Department with the help of Interpol via the Royal Malaysian Police.

Perpetrators of criminal acts of corruption in bad faith deliberately fled to the territorial jurisdiction of 
another country. Due to territorial limitations, the state does not have the authority to enforce law. Law enforcement officers of a country experience territorial constraints in catching criminals because of their territorial jurisdiction. Cooperation between law enforcement officers in each country is one solution to crack down on and eradicate perpetrator of criminal corruption who have fled.

The existence of different perceptions causes problems to occur during law enforcement where the perpetrators should be investigated and prosecuted. Under the provisions of international criminal law, a country does not have the obligation to hand over the perpetrators of criminal acts. Requests for extradition of perpetrators of crimes from countries requested to requesting countries often experience obstacles or cannot be carried out due to the reason that there is no extradition treaty between the two countries. [3]

Nevertheless, the state based on territorial jurisdiction has the right, power, or authority to make or stipulate laws and regulations or decisions to be enforced within its territorial limits, implemented against individuals and or legal entities and prosecute perpetrators of crimes within its territory.

The law enforcement apparatus of each country means is the International Criminal Police Organization (ICPO-INTERPOL) which mandates the National Central Bureau (NCB-INTERPOL) as an agency located in each member country with the aim of minimizing the barriers to territorial jurisdiction in preventing and enforcing the law.

Problems arise because collaborations between police agencies are still limited due to issues of a technical nature. As we know, in international relations, especially relations between countries, each party is faced with the sovereignty of other countries which must be respected. Sovereignty is a barrier factor in preventing, eradicating and punishing perpetrators of international crimes and crimes with an international dimension.

In implementating extradition treaty, it is required that the transfer of the perpetrator of a criminal act is based on a request from the requesting State to the requested State. However, in the practice of relations between States, the surrender of criminals from the requested State does not always require an extradition treaty. Other methods can be implemented with reciprocity.

The implementation of extradition is emphasized based on foreign policy policies with certain aims and objectives. Practically extradition is very much needed in law enforcement in Indonesia. The current trend shows that many corruptors have fled abroad, and without extradition treaties between countries, Indonesian law enforcement cannot pursue, arrest or even detain the perpetrators. However, the problem is that there are still many countries that have not found a common ground to put cooperation in crime prevention into an extradition treaty.[4]

The important thing in the implementation of extradition is not only bringing criminals before the court to be legally responsible for their actions, but in a broader context is an effort to restore assets and prevent similar acts from being repeated because this threatens security and order in the international world order. . This is the responsibility of all countries in the world, especially Indonesia.

The extradition process involves certain procedures, procedures or formalities. For the surrender or extradition of the requested person, there must first be a request to hand over the person concerned from the requesting country to the requested country. Without a prior formal request from the requesting country to the country where the person concerned is located (the requested country), the state may not hand over the person concerned. [5]

A country has the right to refuse the extradition of its own citizens, it becomes a very dangerous space where fugitives take advantage of this principle. There is a fact that some countries are not willing to provide extradition if there is no agreement. Based on this description, the purpose of this study is to find out the obstacles in applicating extradition for law enforcers in carrying out extradition.

\section{RESEARCH METHOD}

The research method used in writing this journal is a normative legal research method. Normative legal research can also be referred to as doctrinal legal research. In this study, law is often conceptualized as what is written in the legislation (law in book) or law is conceptualized as a rule or norm that is a benchmark for community behavior towards what is considered appropriate, relating to extradition. The characteristic of the writing used by the author is descriptive that the research is used to provide data that is as accurate as possible about a symptom or phenomenon, in this case regarding the Legal Analysis of Obstacles in Applicating Extradition for Law Enforcers in Extraditing Perpetrator of Criminal Acts of Corruption. 


\section{RESULTS AND DISCUSSION}

\subsection{The Absence of Extradition Agreements for Law Enforcers in the Applicating Extradition}

Aspects of the long history of the absence of bilateral agreements (extradition) between Indonesia and other countries are suspected to be motivated by conflicts of interest in the political economy between Indonesia and other countries. Indonesia has an interest in promoting the rule of law (eradication of transnational crimes which is corruption). [6]

As one of the mechanisms of international cooperation, extradition is an instrument of law enforcement to find and return a suspect, defendant or convict to the state for trial.

The international community's desire to overcome various procedural obstacles that lead to the effectiveness of extradition as an instrument of law enforcement cooperation is stated in UN Economic and Social Council resolution no. 1997/26 on International Cooperation in criminal matters which basically encourages countries to take steps to increase the effectiveness of the implementation of extradition in their respective countries. [7]

Cooperation relations are carried out by Indonesia with countries that are often used as refugees. In the political field, Indonesia has negotiated several agreements, namely defense agreements and counter terrorism. This indicates a good and productive relationship. However, from the social side, there are pros and cons from various elements of society because the agreement concerns the political and defense fields. [8]

The continuation of the cooperation is in the field of defense and security with the implementation of the Memorandum of Understanding on Bilateral Defense Cooperation concerning cooperation in the fields of military education, law enforcement, research and development, humanitarian assistance, disaster relief, military logistics, medical services, peacekeeping missions and efforts to eradicate corruption. as mandated in the United Nations Convention Against Corruption (UNCAC).

Efforts by perpetrators of criminal acts of corruption to flee abroad is a mode of action to protect themselves from legal snares. In practice, the destination countries as a place of escape are countries that do not yet have an extradition treaty with Indonesia. Even in the case there are perpetrators who are proven to have committed a crime, but before being executed the convict has fled or fled abroad first. There are even those who are tried in absentia, even though the perpetrators are convicted, but the law cannot be applied because the perpetrators cannot be extradited. [9]

Defense cooperation between Indonesia and countries that are often used as refugees such as Singapore is the first step in the form of Indonesia's diplomatic relations in establishing bilateral cooperative relations. As one of the countries that are often used as refugees, the agreement is aimed at improving bilateral relations between the two countries. [10]

Along with the number of international crimes, the police in various parts of the world cannot work alone, therefore cooperation between the police must be further enhanced and optimized. The Indonesian National Police (POLRI) in this case has a very important role, one of which involves the role of Interpol. Interpol plays an important role in facilitating cooperation between national police forces in dealing with transnational crimes. [11]

To be able to overcome these transnational crimes, the POLRI as law enforcers in Indonesia through the National Central Bureau (NCB) coordinates with ICPOInterpol. In an effort to eradicate crime, Interpol will issue red notices and arrest orders to all member countries so that it is possible for each member country to be able to find and arrest perpetrators of criminal acts of corruption. [12]

\subsection{Factors That Become Obstacles in the Implementation of Extradition}

The State of Indonesia is still exploring the negotiation phase of the extradition treaty. Basically the extradition agreement is the key to implementation in the settlement of the extradition case. Globally, countries are guided by the principles and legal rules regarding extradition that have been generally adopted by countries in the world. Extradition institutions have been recognized and accepted by scholars of international criminal law as international customary law. [13]

Countries that adhere to civil law tend to exercise criminal jurisdiction over their citizens by examining whether a violation was committed within the jurisdiction of the country or abroad. The reason for this exception relates to sovereignty which is considered a fundamental right. In some states this is enshrined in the national constitution which function is to determine whether a person is a citizen must be regulated in the national legislation on nationality. [14]

The absence of ratification of the extradition treaty can be overcome by using Mutual Legal Assistance, as well as covert extradition guided by the principle of reciprocity (reciprocity) between each country. The failure to ratify the extradition treaty between Indonesia 
and several countries was due to the difficulty of accommodating the interests of each country. Therefore, the two countries often use multilateral cooperation forums as a forum to communicate and take advantage of the existence of Interpol to handle cases of transnational crimes. However, the effectiveness of these efforts is not so significant, constrained by the problem of differences in the legal system and the sovereignty of each country.

There are several legal obstacles that make extradition difficult for other law enforcers : [15]

a. Differences in understanding the Anglo-American legal system or known as the Common Law System. In this system, it is the courts, not the government, that decide whether a person is extradited or not. The Indonesian government's request for extradition is entirely dependent on the court's decision of the requested country. Therefore, even if its based with good relations, it will be difficult to apply when faced with the application of law in other countries. [16]

b. The principle of reciprocity (principle of reciprocity) states that the state can return an offender to the requesting country of origin and then the act is retaliated by the requested state. In this context, the extradition treaty can actually be implemented without ratification, but the governments of other countries may not follow this principle because it does not have benefits at all. [17]

c. The locus delicti of the occurrence of corruption is clear, but due to money laundering that has been carried out, it is difficult for law enforcement to trace the results of corruption.

d. Many criminals managed to escape abroad, and could not be processed properly for several reasons, (one of them was the protracted administrative and bureaucratic processes that could be easily duplicated). [18]

e. There are significant misconception of corruption between the two countries. Corruption according to Indonesia, namely bribery which contains elements against the law, brings personal or other benefits to the state, and provides harm to the state, while the conception of corruption according to the Anglo Saxon state of corruption is only defined as an act of bribery that does not give any profit to individuals, others and does not cause harm for country.

f. Extradition cannot be carried out immediately because the government is waiting for the parliaments of each country to make laws. Moreover there are still different concepts regarding the meaning of corruption, it can be seen as an example in the 1992 Indonesia-Australia extradition treaty ratified by the house of representative in 1994 or Law No. 2001. The existence of leeway allows the perpetrator to escape to avoid punishment. g. Extradition can only be applied to criminals who have the status of suspects and convicts. Based on Article 1 of Law 1 of 1979 concerning Extradition, it is stated that those who can be extradited are people who are requested by competent officials from foreign countries because they are suspected of committing a crime or to undergo a sentence or a detention order. This means, the extradition treaty will not reach those whose status is still under investigation or who are still in the status of potential suspects.

In addition to legal factors, there are also political factors that have contributed to the obstacles to extradition for law enforcers in Indonesia, namely:

a. Perpetrators of criminal acts of corruption are protected by the principle of non expulsion whereby countries where asylum seekers are located cannot expel asylum seekers who are illegally in their territory except for reasons of national security or public order.

b. There has been no initiation of the ratification of the extradition treaty carried out by the Indonesian government against the governments of other countries. Because the extradition treaty between Indonesia and Singapore concerns state sovereignty.

c. There is no international cooperation between the international criminal police organization (ICPO) Interpol, the government of the republic of Indonesia and the government of the country where the perpetrators of the corruption have fled. [19]

d. The lack of cross-agency cooperation between the Police, the Prosecutor's service and the Judiciary as well as other legal institutions. In practice, one of the authorized agencies in dealing with criminal acts of corruption such as the prosecutor's service and the Corruption Eradication Commission is not responsive in fulfilling the required requirements. This has resulted in delays in the implementation of the extradition by the Indonesian police in the country where the perpetrators of the crime of corruption fled. In addition, the submission of a red notice in the Djoko Tjandra case was not renewed after 5 years. This is a real example of the failure of coordination between agencies.

e. Although the legal framework for the implementation of extradition from the side (legality) such as Indonesia - Singapore supports the negotiation of an extradition treaty. The Multilateral Cooperation Framework (UNCAC) has been ratified in Law no. 7 of 2006. Meanwhile, in the regional area, cooperation is carried out through ASEAN in the fields of politics and security. The government is considered to have no Political Will because the government is more accommodating of domestic political activities. 
f. The criminal justice system that adheres to the Due Process Model / DPM (emphasizing the protection of human rights for suspects, causing a long bureaucracy in criminal justice) and there are those who choose the Crime Control Model / CCM based on the principle of presumption of innocence.

g. Lack of willingness to be involved in the working group cooperation forum on the ASEAN Extradition Treaty model in accommodating foreign policy interests to overcome and increase cooperation related to extradition issues.

The problem of conflicting political and legal interests from each country is also one of the obstacles, especially in terms of exchanging information and the identity of criminals. This issue will come to the fore when implementing the extradition treaty. Based on these several factors and interests, Indonesia can apply international standards in extraditing perpetrators of criminal corruption by utilizing the legal framework and so on. In addition, Indonesia can urge the international community to conduct extradition regarding issues related to extradition of corruptors through the application of Mutual Legal Assistance (MLA), asset recovery, and other legal institutions.

There are several requests for extradition from other countries, at the initiative of the integrated team looking for convicts and suspects in corruption cases, namely:

a. Singapore in the BLBI Modern Bank case, convict Samadikun Hartono,

b. Singapore in the case of illegal logging Adelin Lis.

c. Singapore in the case of BLBI Bank Aspac Setiawan Harjono and Hendrawan Harjono

d. Singapore in the case of Bank Dewa Rutji Sjamsul Nursalim BLBI

e. Singapore in the case of BLBI National Commercial Bank Kaharudin Ongko

f. Singapore in the case of BLBI Bank Pelita Istimarat Agus Anwar

g. Singapore in the case of BLBI Bank Dharmala Sujanto Gondokusumo

h. Singapore in the case of BLBI Bank Putera Surya Perkasa Trijono Gondokusumo

i. Singapore in the case of BLBI Orient Bank Kwan Benny Ahadi

In order to follow up on various crimes committed outside the territory of a country, criminal law recognizes the expansion of territorial jurisdiction. The territorial expansion includes technical expansion, extension based on protection principle, and expansion based on universal principle. This technical extension is divided into subjective territorial principles and objective territorial principles. The subjective territorial principle confirms that the state has the competence to adjudicate acts committed in its territory, but ends up or has an impact on the territory of other countries. While the objective territorial principle confirms that the state has the competence to prosecute acts committed in other countries, but have consequences in their territory. The criminal law legislation of a country applies to all people outside the territory of their country when committing crimes related to security, harmony and integrity or the economic interests of their country. [20]

ICPO-Interpol is helping to return fugitives who fled to a country that does not have an extradition treaty with Indonesia. Interpol helps to resolve transnational crimes that are prosecuted under the jurisdiction of domestic/national law, not under the jurisdiction of international courts or other ad hoc tribunals. Because one of the elements of transnational is the existence of cross-border, inter-state cooperation is needed to complete the law enforcement process. [21]

With the existence of international agreements, both bilateral and multilateral, countries have a strong legal basis to cooperate in the prosecution of international crimes. The absence of an extradition treaty can be implemented by applying the principle of reciprocity. As in the case of Tomas Toman who is a fugitive from the Czech Republic government who fled to Indonesia and the Indonesian government extradite him without an extradition treaty between the two countries.

Cooperation in law enforcement in international relations has proven to be crucial to the success of national law enforcement against transnational crimes. In general, the success of law enforcement cooperation will not become a reality if there is no bilateral or multilateral agreement in handing over the criminals or in cooperation in investigation, prosecution and trial.

As part of efforts to repatriate criminals who have fled and are hiding abroad, in addition to the need for an agreement, both bilateral and multilateral as a basis for extradition requests and Mutual Legal Assistance (MLA) to be carried out through handing over efforts against perpetrators of criminal acts to overseas. If the country used the place of hiding and escape does not yet have an extradition agreement or a Mutual Legal Assistance (MLA) agreement with the Indonesian government.

Extradition can be carried out in two ways, namely through the treaty itself or international etiquette. Without an extradition agreement, the transfer of the perpetrator can be reached through Handing Over or Disguished Extradition (submission of the perpetrator of a criminal act in a disguised way), not through the official extradition procedure. The principle of good relations has advantages over the extradition treaty. The relationship between the government and the police between countries through Handing Over will save the costs and time required by going through the extradition treaty 
procedure. On the other hand, with the existence of an agreement, the state has the obligation and right to surrender or request the surrender of a person.

Handing Over is carried out based on tactical considerations and provisions based on the applicable extradition provisions. In addition, the principle of reciprocity and mutual interest between the requesting country and the requested country. International cooperation that aims to enforce criminal acts, it is necessary to take special actions. The special action is in the form of Handing Over (handing over the perpetrators of criminal acts) from one country to another, where this is considered very efficient, simple, and fast.

The extradition treaty is an extension of conventions and procedures for the application of international criminal law. In addition to several alternatives, related to the process of carrying out extradition, the government and law enforcement must increase the intensity of formulating extradition agreements with other countries. In practice, countries with civil law systems show a greater will to agree to extradition even though there is no agreement between countries in the form of reciprocity.

Indonesia and other member countries have interests and goals to be achieved regarding the establishment of the ASEAN Extradition Treaty, among others, in the context of strengthening Indonesia's bilateral and multilateral relations with neighboring countries, and strengthening ASEAN. As its expected that through the ASEAN Extradition Treaty, the pursuit of perpetrators and assets taken abroad can be carried out more quickly and can overcome other forms of transnational crime. [22]

\section{CONCLUSION}

Constraints in applicating extradition for law enforcers are strongly influenced by the direction of domestic legal politics. The direction of international relations that has not yet been determined greatly influences the decision on the follow-up to the extradition process for perpetrators of corruption. The perpetrators of criminal acts of corruption tend to take advantage of loopholes in the absence of extradition treaties against countries that are used as places of escape. Nevertheless, Indonesia, through law enforcers, seeks to extradite criminals to account for their actions.

\section{ACKNOWLEDGMENTS}

The researcher would like to thank the University of North Sumatra (USU), especially the Doctoral Program of the Faculty of Law, USU which has provided facilitation in the publication of this scientific work, hopefully this work can be useful and become a reference for the development of future legal research.

\section{REFERENCES}

[1] D. M. N. Dewi, I. M. Sepud, and I. N. Sutama, "Ekstradisi Sebagai Upaya Pencegahan Dan Pemberantasan Kejahatan Internasiona," $J$. Analog. Huk., vol. 2, no. 1, pp. 17-21, 2020, doi: 10.22225/ah.2.1.1610.17-21

[2] Flora Pricilla Kalalo, "Efektivitas Perjanjian Ekstradisi Sebagai Sarana Pencegahan, Pemberantasan dan Penghukuman Pelaku Tindak Pidana Internasional," Lex Soc., vol. 4, no. 2, pp. 13-22, 2016.

[3] N. S. Damayanti, "Kedudukan perjanjian ekstradisi dan pengembalian aset dalam penegakan hukum pidana internasional terhadap pelaku tindak pidana korupsi di indonesia," $J$. Huk. Pidana Dan Pembang. Huk., vol. 1, no. 2, pp. 1-12, 2014.

[4] I. N. Ardika, "Akibat Hukum Ekstradisi Ilegal yang Dilakukan Penegak Hukum Negara Pengekstradisi," Advokasi, vol. 3, no. 2, p. 120, 2014.

[5] I Made Krisna Adiwijaya, "Ekstradisi Sebagai Sarana Pemberantasan Kejahatan Internasional Ditinjau dari UU No. 1 Tahun 1979," vol. VII, no. Lex Et Societas, pp. 121-128, 2019.

[6] I. M. R. Mahayasa, "Perjanjian Ekstradisi Antara Indonesia dengan Singapura Sebagai Upaya Pengembalian Pelarian Koruptor Indonesia di Singapura," Univ. Brawijaya, p. 16, 2012.

[7] J. S. Maringka, Ekstradisi dalam Sistem Peradilan Pidana. Jakarta: Sinar Grafika, 2018.

[8] T. Karomah, "Kerjasama Pertahanan Indonesia Jerman Melalui Deklarasi Jakarta," JOM Fisip, vol. 4, no. 2, pp. 92-105, 2017.

[9] N. Y. Malinda, “Analisis Yuridis Kerjasama Antara International Criminal Police Organization Dengan Kepolisian Negara Republik Indonesia Dalam Melakukan Pencarian dan Penangkapan Pelaku Tindak Pidana Korupsi yang Melarikan Diri Ke Luar Negeri," Jom Fak. Huk., vol. V, no. 2, pp. 1-15, 2018.

[10] Poerwadarminta, Ekstradisi dalam Hukum Internasional dan Hukum Nasional. Bandung: Mandar Maju.

[11] Mario Savino, Global Administrative Law Meets Soft Powers: The Uncomfortable Case Of Interpol. New York: Journal of International Law and Politics, 2011.

[12] Eddy Damian, Kapita Selekta Hukum Internasional. Alumni, 1991.

[13] S. Hartono, Pembinaan Hukum Nasional dalam 
Suasana Globalisasi Masyarakat Dunia. Bandung: Fakultas Hukum Universitas Padjajaran.

[14] V. Stefanoska, "EXTRADITION AS A TOOL FOR INTER-STATE INTER STATE COOPERATION : RESOLVING ISSUES ABOUT THE OBLIGATION TO EXTRADITE Vesna Stefanovska, PhD Student," J. Lib. Int. Aff., vol. 2, no. 1, pp. 38-48, 2016.

[15] I. W. Parthiana, Hukum Pidana Internasional dan Ekstradisi. Bandung: Yrama Widya, 2003.

[16] S. Syarifuddin, "Relevansi Undang-Undang No. 1 Tahun 1979 Tentang Ekstradisi Dengan Perkembangan Hukum Ekstradisi Internasional (Studi Kasus: Perjanjian Ekstradisi IndonesiaSingapura)," J. Komun. Huk., vol. 2, no. 1, pp. 94-113, 2016, doi: 10.23887/jkh.v2i1.7284.

[17] D. WARYENTI, "Ekstradisi Dan Beberapa Permasalahannya," FIAT JUSTISIAJurnal Ilmu Huk., vol. 5, no. 2, 2014, doi: 10.25041/fiatjustisia.v5no2.64.

[18] Fitriyani, "Peranan perjanjian ekstradisi dalam menanggulangi kejahatan korupsi di indonesia," Lex Justitia, vol. 1, no. 2, pp. 140-158, 2019.

[19] Fauzin, "Peran Perjanjian Ekstradisi dalam Penegakan Hukum Tindak Pidana Korupsi di Indonesia," RechtIdee, vol. 16, no. 1, pp. 133155, 2021.

[20] Eddy O.S Hiariej, Hukum Pidana Internasional. Jakarta: Erlangga, 2009.

[21] T. Effendi, Hukum Pidana Internasional. Yogyakarta: Pustaka Yustisia, 2014.

[22] A. Mangasi, "KEPENTINGAN INDONESIA DALAM PROSES PEMBENTUKAN PERJANJIAN EKSTRADISI THE ASSOCIATION OF SOUTH EAST ASIAN NATIONS ( ASEAN ) Abstrak," pp. 1-16. 